\title{
Studies on white-spored agarics
}

\author{
HARRI HARMAJA
}

\begin{abstract}
HARMAJA, H. 1985: Studies on white-spored agarics. - Karstenia 25: 41-46.
The following new species are described (all the types are from Finland): Cystoderma saarenoksae Harmaja, Cystoderma niveum Harmaja, Hygrophorus korhonenii Harmaja Mycena lammiensis Harmaja, and Mycena occulta Harmaja. Melanoleuca brachyspora Harmaja (nomen novum) must replace $M$. brevispora Harmaja (non Singer). The following new combination is made: Hygrophorus subviscifer (Karst.) Harmaja. Hygrophorus albidus Karst. (lectotype selected here) and $H$. spodoleucus Moser are reduced to synonymy with $H$. subviscifer. Mycena pelianthina (Fr.) Quél. is reported as new to Finland.
\end{abstract}

Harri Harmaja, Botanical Museum, University of Helsinki, Unioninkatu 44, SF-00170 Helsinki, Finland

Cystoderma saarenoksae Harmaja n.sp. -Fig. 1 A Cystodermate lilacipedi praecipue differt coloribus luteofulvis pilei stipitisque, forma sporarum leniter dissimili, et crassitudine sporarum minore (sporae 5.5$7.5 \times 2.7-4.0 \mu \mathrm{m})$. - Typus: Finland, Uusimaa: Helsinki, Vanhakaupunki, Annala, siliceous rock outcrops, on or among the mosses Polytrichum juniperinum, $P$. piliferum, Dicranum scoparium, etc., associated with e.g. Betula sp., Pinus sylvestris, Quercus robur, Sorbus aucuparia, Calluna vulgaris, and Cystoderma lilacipes, Grid 27 $\mathrm{E}$ : 6679:387, 13.X.1980 Reima Saarenoksa 72380 (H, holotype; L, isotype).

In the late 1970's Mr. Reima Saarenoksa (Department of Botany, University of Helsinki) and I gradually realized that this taxon existed in South Finland. In the course of time it became clear that it was an undescribed species, closely related to Cystoderma jasonis (Cooke \& Massee) Harmaja and especially to C. lilacipes Harmaja. Mr. Saarenoksa collected a large amount of very well-preserved and annotated specimens of this new species, and it is may pleasure to name it in his honour.

C. saarenoksae is separated from C. lilacipes (see Harmaja 1979) by the yellow-brown or fulvous colours of the pileus and the stipe, the more yellowtinged lamellae, and the slightly narrower and somewhat differently shaped spores (mostly subfusiform, some fusiform and some ellipsoid). The new species differs from C. jasonis (see Harmaja 1979) in the often smaller fruit bodies, the smaller granules on the surfaces of the pileus and the stipe (those of pileus surface hardly visible to the naked eye), the very pale brown cap context, the slightly smaller spores, and the absence of arthrospores from the cap context. C. saarenoksae differs from C. amianthinum (Scop.) Konr. \& Maubl. (see Harmaja 1979) in the often smaller basidiocarps, the usually smaller granules of the pileus surface, the yellow or yellowish buff lamellae, the slightly tinged cap context, the predominantly subfusiform shape of the spores, the lack of thick-walled cyanophilic and somewhat dextrinoid sclerospores and sclerobasidia, and the more coarsely encrusted walls of the sphaerocysts.

C. saarenoksae shares the interesting ecological features of C. lilacipes (cf. Harmaja 1979). Both species fruit in South Finland from late September to early December, growing on \pm acid rock outcrops, even rocks distinctly influenced by man, and also in fens and bogs. The fruit bodies are usually attached to the stems of the moss Polytrichum juniperinum, and also to those of $P$. piliferum, Dicranum scoparium, and Racomitrium lanuginosum (infrequently a few other moss species). Consequently, $C$. saarenoksae and $C$. lilacipes very commonly grow together in the same habitats. C. amianthinum and C. jasonis can also be found in such habitats late in the autumn, but they begin to fruit earlier and also occur in forest; moreover, they are very frequently attached to Dicranum polysetum (cf. Harmaja 1979). The apparently fairly common occurrence of $C$. saarenoksae and C. lilacipes on Polytrichum hummocks on peatland was observed only recently, and is here reported for the first time.

C. saarenoksae (like C. lilacipes) has proved to be common at least in southern Finland, and several dozens of specimens have been collected from the biological provinces Varsinais-Suomi, Uusimaa, Etelä-Karjala, and Etelä-Häme.

A more thorough paper on this and the following species is under preparation.

Cystoderma niveum Harmaja n. sp.

A Cystodermate jasonis plurimum differt statura minore, pileo stipiteque hyalineo ad niveo, superficie pilei laevi (sed sub lente ruguloso), lamellis pallide roseis (raro albis), carne albo, tunica sphaerocystium sine incrustatione, et hyphis pilei non conidiiferis. - 


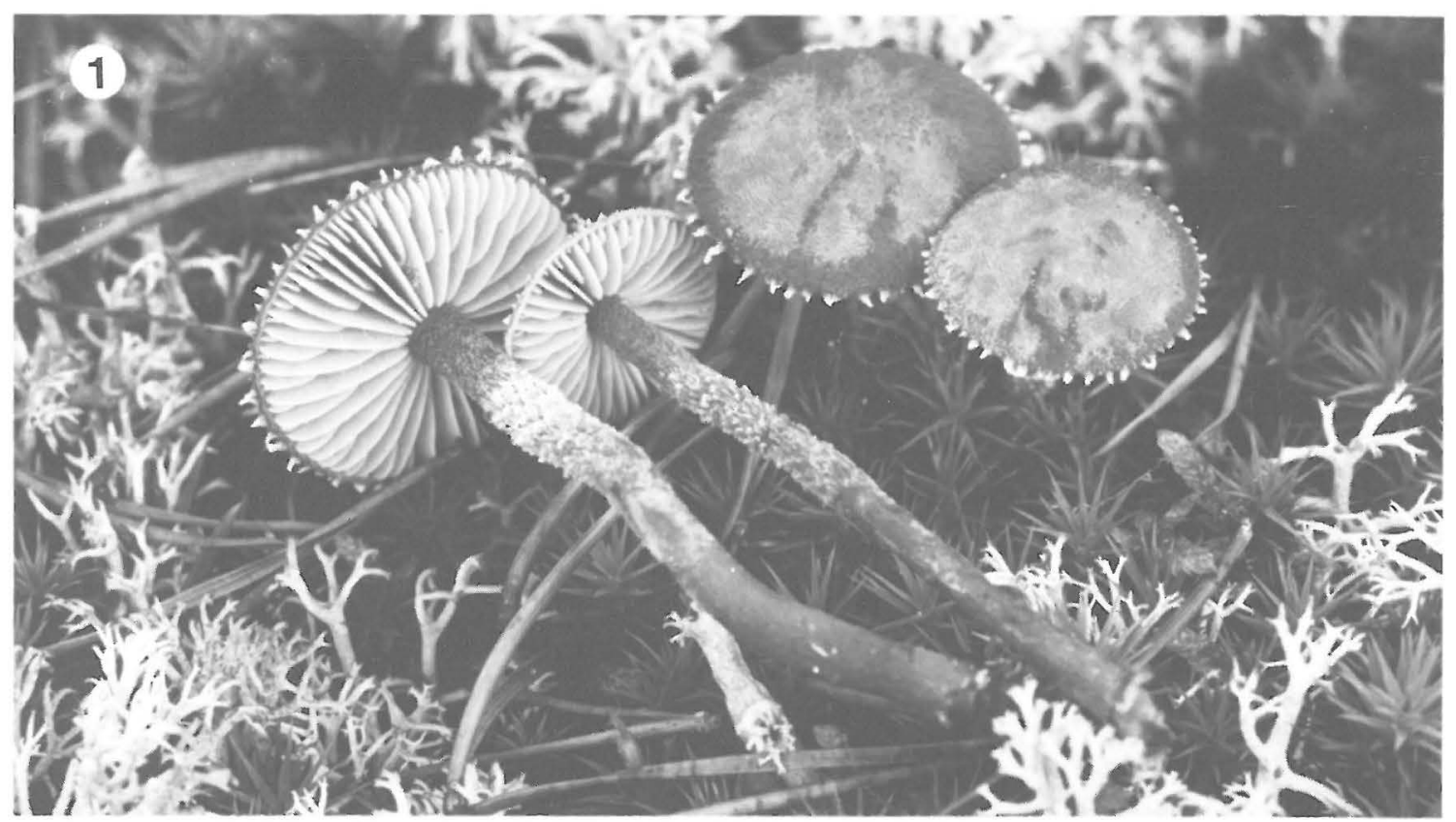

Fig. 1. Cystoderma saarenoksae fresh in situ, $\times 1.5$ (Finland, Uusimaa, Espoo, Espoonkartano, Grid 27²E: 6679:367, 20.X.1979 Korhonen 3059; H). - Photo: Mauri Korhonen.

Typus: Finland, Uusimaa: Espoo, Tapiola, Suvikumpu, alt. $20 \mathrm{~m}$, acid, siliceous, \pm distinctly man-influenced rock outcrops, on or among mosses such as Dicranum scoparium and Polytrichum juniperinum, associated with e.g. Betula sp., Pinus sylvestris, Cantharellula umbonata, Cystoderma jasonis, C. lilacipes, C. saarenoksae, Laccaria cf. proxima, Grid $27^{\circ} \mathrm{E}$ : 6677:377, 14.XI.1981 Harri Harmaja (H).

This new species is very easily recognized, as its pileus and stipe are hyaline when wet and snow-white when only moist or dry. The surface of the pileus is smooth to the naked eye, but the stipe (except for the apex) is finely granular and usually shows an indistinct ring zone. The lamellae are slightly sinuate or almost decurrent, subdistant, usually fairly narrow, and usually pinkish, rarely hyaline or whitish, in all conditions. Older pilei, at least when they are dry, may turn grey or yellowish at the disc and may have reddish or even bright red spots in places (apparently due to injury or decay), and older stipes become ivory towards their bases, at least when dry. The spores of $C$. niveum measure $5.5-8.0 \times$ $3.0-4.5 \mu \mathrm{m}$, most of them being subfusiform, some ellipsoid and a few fusiform; the spore walls are amyloid. Sclerobasidia and sclerospores (see Harmaja 1979) are lacking, the sphaerocyst walls are not encrusted but hyaline, and arthrospores are absent from the white cap context.

When first found, $C$. niveum was mistaken for a Camarophyllus because of its colours and habit. Its characters separate it from all the other white species and the \pm albinotic forms of certain coloured species of Cystoderma, and it does not seem to be an albino itself. Its closest congeneric relative appears to be $C$. saarenoksae Harmaja (see above).

\section{Specimens examined}

Finland. Uusimaa: Espoo, Tapiola, 14.XI.1981 Harmaja (type; H); the same place, with e.g. C. amianthinum, 17.X.1982 H. \& T. Harmaja (H). Helsinki, Viikki, Hakala, rock outcrops among especially Dicranum scoparium, Polytrichum juniperinum being also present, Grid $27^{\circ} \mathrm{E}$ : 6680:389, 19.X.1985 Saarenoksa $52585(\mathrm{H})$.

Hygrophorus korhonenii Harmaja n.sp. - Fig. 2 Sicut Hygrophorus olivaceoalbus sed differt statura saepe maiore, forma pilei typice \pm campanulato, colore pilei cum tincto griseo, velo dissimili, et sporis minoribus, 10.0-14.0 × 5.2-7.5 $\mathrm{m}$. - Typus: Finland, Koillismaa: Kuusamo, Liikasenvaara, Sirkkapuro, fairly rich spruce forest near Siikauopaja, Grid $27^{\circ} \mathrm{E}$ : 7362:612, 29.VIII.1977 Mauri Korhonen 1950 \& Tauno Ulvinen ( $\mathrm{H}$, holotype; OULU, isotype).

Pileus $2-8 \mathrm{~cm}$ in diam, grey-brown with a blackbrown centre, radiately dark-striate, conical at first then expanding to (usually) broadly campanulate with a prominent subacute umbo; surface viscid or slimy; fibrils of dry inner velum hanging at the margin of young pileus. Stipe ca. $7-12 \times 0.5-2.0 \mathrm{~cm}$, apex dry, white and very delicately pubescent (without granules), the major part \pm weakly viscid (at times even appearing dry) and of the colour of cap margin or slightly paler, irregularly zonate when fresh but mostly unicolorous when dry; white, later often 


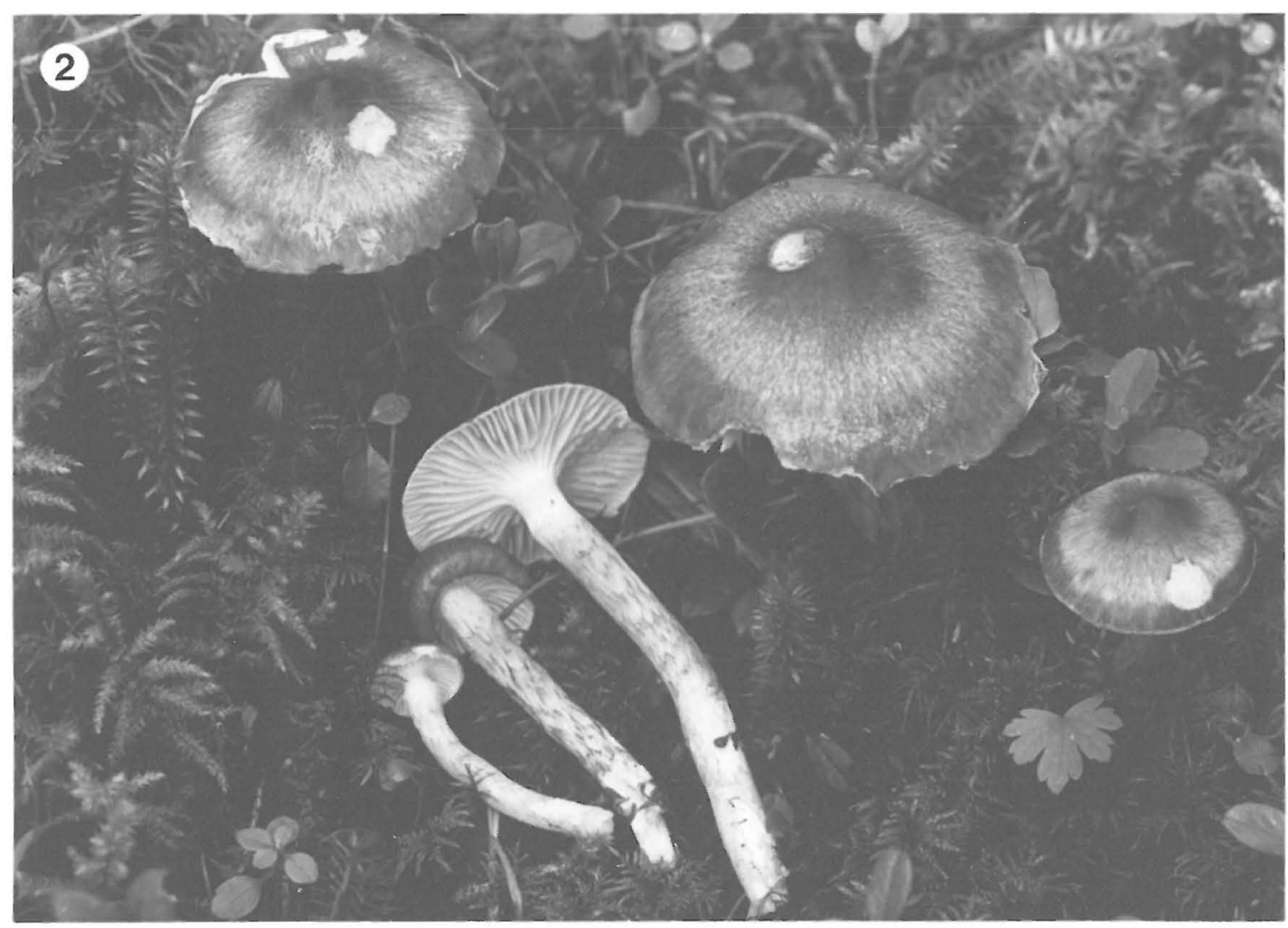

Fig. 2. Hygrophorus korhonenii fresh in situ, $\times 0.8$ (type). - Photo: Mauri Korhonen.

brownish, fibrils of dry fibrillose inner velum and very narrow dark teeth of the broken slimy outer velum present at ring zone (the fibrils also present further down where the slime has worn off), these fibrils and teeth wearing off in time. Lamellae, odour, taste and context about as in $H$. olivaceoalbus. Spores $10.0-$ $14.0 \times 5.2-7.5 \mu \mathrm{m}$, most fairly narrowly ellipsoid and oblong, the remainder (rarely the majority) obovoid, sometimes also a few lacrymoid spores present; wall hyaline, smooth, inamyloid. Basidia up to ca. $65 \times 10 \mu \mathrm{m}, 4$-spored. Cystidia none. Cortex of pileus an ixocutis, fairly gradually delimited from the context, hyphae ca. 2.5-7.0 $\mu \mathrm{m}$ in diam, subparallel to somewhat interwoven, only vacuolar pigment present, appearing as medium brown to dark brown granules; extracellular granules absent. Pubescence at stipe apex composed of hyphae in loose bundles, 5$10(-14) \mu \mathrm{m}$ in diam, equal or very slightly narrowed or enlarged toward their apices. Clamps common in context and cutis. Ecology. Usually in mesotrophic and meso-eutrophic woods, including paludified ones, at times on oligotrophic ground, always associated with spruce (Picea abies in Fennoscandia); from the middle of August to late October. Distribution. Hemiboreal to northern boreal, from sea level up to at least $630 \mathrm{~m}$; not uncommon in Finland from the south coast to Kuusamo in the north.
This species is named in honour of Mr. Mauri Korhonen (Botanical Museum, University of Helsinki), a well-known mycologist and photographer, who also noticed the existence of the present taxon.

The heterogeneity of the current concept of Hygrophorus olivaceoalbus (Fr.: Fr.) Fr. has been noted by several Finnish mycologists (e.g. Tuomikoski 1976). My studies on mainly Finnish material revealed that a species aggregate is indeed concerned. The delimitation and nomenclature of the segregates are still partly incomplete, but the present species is well defined and was found to require a name. $H$. 'olivaceoalbus var. olivaceoalbus' in Hesler \& Smith (1963) fits the diagnostic characters of $H$. korhonenii. Arnolds (1979) correctly remarked that the taxon of the North American authors is not the true $H$. olivaceoalbus; he determined it as 'Hygrophorus sp.'.

$H$. korhonenii differs from $H$. olivaceoalbus s. str. mainly in the following respects: the fruit bodies are often somewhat larger, the pileus is usually broadly campanulate, the umbo of the pileus is more prominent, the colour of the cap displays a grey tinge, the surfaces of the cap and the stipe are somewhat less viscid, an inner dry fibrillose velum is present (see the description), the spores are smaller (about 10.5-16.0 
$\times 6.7-8.7 \mu \mathrm{m}$ in $H$. olivaceoalbus), the habitat is generally more fertile, and the distribution may be generally more northern. There are also differences in the anatomical characters of the pileus cortex and the stipe apex, the shape of the spores, and the size of the basidia.

In the $\mathrm{H}$ collections I have examined 38 specimens of this species from Finland, two from Sweden (Jämtland, Undersåker, Korhonen 5440; Lule Lappmark, Jokkmokk, P. \& I. Kytövuori 80230), one from Norway (Oppland, Nordre Land, Korhonen 6130), and two from Canada (Québec, DAOM 48914 and 93139).

\section{Hygrophorus subviscifer (Karst.) Harmaja n.} comb.

Agaricus subviscifer Karst., Medd. Soc. F.Fl. Fennica 2: 171. 1878 (Symb. Mycol. fenn. 4). - Clitocybe subviscifer (Karst.) Karst., Bidr. Känned. Finlands Nat. Folk 32: 65. 1879 (Hattsvampar 1). - Lectotype (Herb. P.A. Karsten no. 225, $\mathrm{H}$; selected by Harmaja 1969) and three isolectotypes (2 in $\mathrm{H}$, one in UPS) examined: Finland, Etelä-Häme: Tammela, Syrjä, 25.IX.1877 P.A. Karsten.

Hygrophorus albidus Karst., Acta Soc. F.Fl. Fennica 9: 3. 1893 (Symb. Mycol. fenn. 32). - Lectotype (Herb. P.A. Karsten no. 2885, H; selected here) examined: Finland, EteläHäme: Tammela, Syrjä, in abiegno, 24.IX.1892 P.A. Karsten. Another specimen of the type material was collected by Karsten in the same place on 7.IX.1892 (Herb. P.A. Karsten no. 2886, H); I found it conspecific.

?Hygrophorus cinereipallens A.H. Smith \& Hesler, Sydowia 8: 309. 1954. - Holotype from Michigan, U.S.A. (not seen).

Hygrophorus spodoleucus Moser, Zeitschr. Pilzk. 33: 1. 1967. - Holotype from Switzerland (not seen).

This long overlooked species has become fairly well known in recent times, thanks to the description of Moser (1967, as H. spodoleucus). However, he did not realize that Karsten had already given it two different names: Agaricus subviscifer and Hygrophorus albidus. Singer (1943) believed that $A$. subviscifer is a synonym of Hygrophorus eburneus (Bull.) Fr. (a companion of the beech, and not known from Finland!), while I earlier (Harmaja 1969) merely noted that it represents some species of Hygrophorus Fr. North American species that are closely related to, if not identical with, $H$. subviscifer are $H$. cinereipallens A.H. Smith \& Hesler, H. subpungens A.H. Smith \& Hesler, and $H$. sublutescens Hesler \& A.H. Smith (especially the firstnamed) (cf. Hesler \& Smith 1963).

$H$. subviscifer occurs locally in Finland, from the south coast to northern parts of the country, from the hemiboreal to the northern boreal zone. It probably always grows on the needles of spruce (Picea abies), and is met with in both oligotrophic heath forest and in fertile, even calcareous, rich forest.

Melanoleuca brachyspora Harmaja nom. nov. Melanoleuca brevispora Harmaja, Karstenia 18: 30. 1978 (non M. brevispora Singer, Sydowia 8: 116. 1954.)

The holotype of the present species was compared with that of Melanoleuca microspora Gillman \& O.K. Miller (Gillman \& Miller 1977), borrowed from VPI. As a result it was confirmed that $M$. brachyspora is distinct from $M$. microspora, though the species are closely related. The fruit bodies of $M$. brachyspora are larger, the pileus is slightly darker brown with a stronger grey tinge, the spores are slightly smaller, the spore warts are somewhat sparser, the spore plage is less sharply delimited, and cystidia appear to be completely lacking (in $M$. microspora a very few inconspicuous \pm bottle-shaped cheilocystidia were observed). M. microspora has not been proved to occur in Europe; there are interesting collections from Finland (e.g. from Kuusamo and Lohja) which have small spores and lack cystidia, but they are not conspecific with $M$. microspora. These collections seem more closely related to $M$. brachyspora, but are probably not conspecific with it either.

Mycena lammiensis Harmaja n.sp. - Figs. 3-4 Mycenae pelianthinae valde proxima. Ab ea praecipue differt sporis maioribus $(6.0-9.0 \times 3.5-5.0 \mu \mathrm{m})$ et cystidiis tenuioribus (crassitudine 7.0-12.0 $\mu \mathrm{m}$ ). Typus: Finland, Etelä-Häme: Lammi, Hauhiala, S shore of Lamminjärvi, in decaying leaves of Alnus incana, Grid 27E: 6775:395, 5.IX.1978 Anne Sairanen (H).

Pileus ca. $1.0-5.0 \mathrm{~cm}$ in diam, at first convex, remaining so or becoming irregularly plane with an undulating partly elevated margin, hygrophanous, weakly translucent-striate when moist, sordid lilac when fresh, more brownish in age; surface dry, slightly rugose. Stipe ca. 3.0-7.0 $\times 0.3-1 \mathrm{~cm}$, enlarged downwards, basally again narrowed and even shortly radicating, pale sordid lilac, yellowish at base, soon hollow; surface dry, towards apex covered with conspicuous very small dark violet granules. Lamellae sinuate or almost 'decurrent, sordid lilac, with entire dark violet edges. Odour distinctly of radish. Taste mild, of radish. Context without milk; all parts of basidiocarp often blacken in drying. Spores 6.0-9.0 × 3.5-5.0 $\mu \mathrm{m}$, partly narrowly ellipsoid, partly e.g. subphaseoliform; wall smooth, amyloid. Basidia 4-spored. Cheilocystidia 55-90 $\times$ $7.0-12.0 \mu \mathrm{m}, \pm$ fusiform, with long narrow necks; pleurocystidia otherwise similar but shorter, 40-65 $\mu \mathrm{m}$ long, and necks at times slightly thicker and more obtuse. Hymenophoral trama composed of strongly dextrinoid hyphae; clamp connections present. Ecology. Found in mesotrophic and eutrophic (calcareous) woods, chiefly in decaying leaves of Alnus incana, rarely on needles of Picea abies; causes white rot in the litter; in late August and early September.

Specimens examined

Finland. Etelä-Häme: Lammi, Hauhiala, $\mathrm{S}$ shore of Lamminjärvi, 5.IX.1978 Sairanen (type; H), 11.IX.1979 Alanen (H), 7.IX.1982 Harmaja (H), 6.IX.1983 Harmaja (H); Hauhiala, hill SSE of Lamminjärvi, Grid $27^{\circ} \mathrm{E}$ : 6774:395, 9.IX.1980 Harmaja $(\mathrm{H})$. Pohjois-Savo: Vehmersalmi, Puutosmäki, Pitkälahti, 30.VIII.1985 Huhtinen 85/85 (H, TUR).

During my mycology courses in Lammi, South Finland (southern boreal zone), this agaric has been found repeatedly in one place and once in another place near by. In the first place it grew in alder leaves and was associated with, for example, Clitocybe 


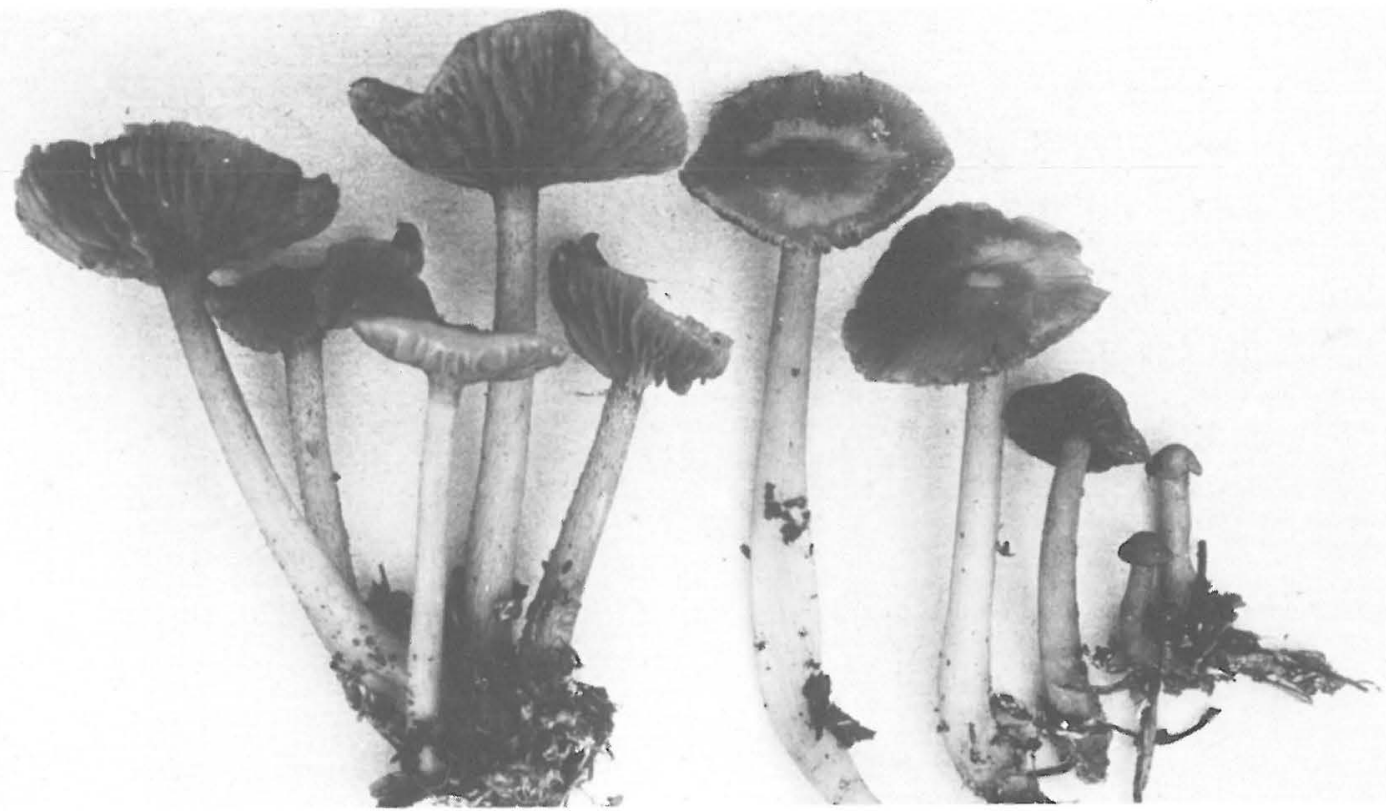

Figs. 3-4. Mycena lammiensis fresh. $-3: \times 1.1 .-4: \times 3$. Photo: Tuomo Niemelä.

menthiodora Harmaja, in the latter place it grew in spruce needles and was associated with Otidea tuomikoskii Harmaja. In other years the second place harboured several other interesting species, such as Mycena cf. cyanorrhiza Quél., M. picta (Fr.) Harmaja, Otidea formicarum Harmaja, Psatyrella caputmedusae (Fr.) Konr. \& Maubl., Sowerbyella brevispora Harmaja (Harmaja 1984; M. lammiensis was mentioned in this paper as $M$. cf. rutilantiformis Murr.), and Squamanita cf. paradoxa (A.H. Smith \& Singer) Bas.

$M$. lammiensis is separated from the very $\operatorname{similar} M$. pelianthina (Fr.) Quél. by the somewhat larger (especially broader), generally slightly differently shaped spores, and the narrower cystidia, which generally have longer and narrower necks. The spores of $M$. pelianthina measure $5.5-8.0 \times 2.7-4.0 \mu \mathrm{m}$, the majority being subphaseoliform (i.e. oblong cylindric with a very low constriction, and very slightly curved), and the cystidial width is 8.5-16 $\mu \mathrm{m} . M$. lammiensis differs from the North American $M$. rutilantiformis (Murr.) Murr. (the holotype in NYS compared) in the slightly smaller spores (they are $6.5-10.0 \times 3.8-5.5 \mu \mathrm{m}$ in the latter) and the characters of the cystidia, the cystidia of $M$. rutilantiformis being dissimilar in approximately the same way as those of $M$. pelianthina. There may also be some macroscopic differences between $M$. lammiensis and the two other species, and they may prefer different substrates. $M$. lammiensis may prove to have a more northern distribution than the others.

$M$. pelianthina, $M$. rutilantiformis and $M$. lammiensis form a group of very closely related taxa, but they appear to be distinct enough to be recognized

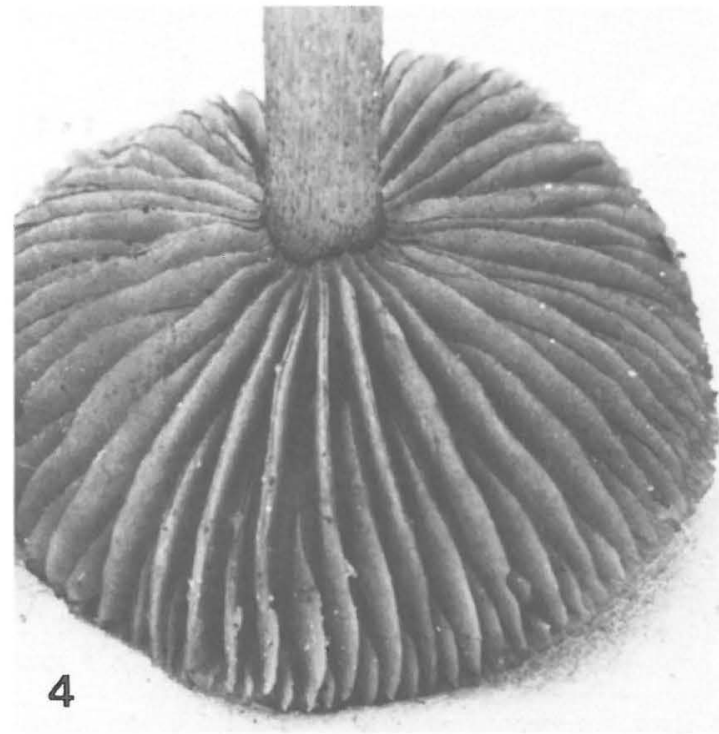

at the specific level. Maas Geesteranus (1980), for example, recognized both $M$. pelianthina and $M$. rutilantiformis.

Very recently, $M$. pelianthina was found as new to Finland; I have examined the following specimen: Uusimaa, Helsinki, Myllypuro-Puotinharju, rich forest, in litter of various deciduous trees (but no Alnus, Fagus or Quercus!) and herbs, Grid $27^{\circ} \mathrm{E}$ : 6680:393, 19. VIII.1985 Saarenoksa 25685 (H, TUR).

Mycena occulta Harmaja n.sp.

Mycenae adscendentis sat similis. Ab ea plurimum differt pileo minore e cyaneo albescente, sporis 
tenuioribus, basidiis quattuor sporis, cheilocystidiis dissimilibus, et substrato non lignoso. - Typus: Finland, Uusimaa: Helsinki, Viikki, Hakala, rich woods, on decaying needles of Picea abies and Pinus sylvestris, Grid $27^{\circ} \mathrm{E}$ : 6680:389, 16.VIII.1982 Reima Saarenoksa $15182(\mathrm{H})$.

Pileus ca. 0.5-2 $\mathrm{mm}$ in diam, campanulate-convex, pale blue but turning white immediately when picked; surface viscid, granular under magnification, usually slightly sulcate. Stipe ca. 5-20 (-30) $\times 0.1 \mathrm{~mm}$, translucent, very pale blue but turning white almost immediately when picked, hyaline-white and shining when dry; surface viscid, appearing glabrous or nearly so also under magnification; very small white basal disc present. Lamellae narrowly adnate (may appear free at times), white, narrow, distant, ca. 8 reaching the stipe. Spores $6.5-10.0 \times 3.7-5.0 \mu \mathrm{m}$, most narrowly ellipsoid and oblong, a few to many obovoid and clavate, and some moderately ellipsoid and lacrymoid (at times also some cordiform spores present); wall smooth, \pm weakly amyloid; at times many spores having germinated at their apical ends. Basidia 13-17 $\times 7-10 \mu \mathrm{m}$, clavate or obpyriform, 4-spored. Cheilocystidia ca. 15-30×6-13 $\mu \mathrm{m}, \pm$ clavate, densely covered with short blunt or truncate papillae; pleurocystidia apparently absent. Hymenophoral trama composed of strongly dextrinoid hyphae. Pileus trama consisting of \pm inflated cells with smooth dextrinoid walls. Pileus cortex composed of globose or obpyriform pedicellate terminal cells, $12-30 \mu \mathrm{m}$ in diam, covered with dense blunt or truncate papillae ca. $1-2 \mu \mathrm{m}$ long and $0.7-1.7 \mu \mathrm{m}$ thick. Stipe trama consisting of strictly parallel smooth or rough dextrinoid clamped hyphae, ca. 5$17 \mu \mathrm{m}$ in diam. Caulocystidia scattered, inconspicuous, \pm lageniform, clamped, ca. 25-100 $\mu \mathrm{m}$ long, basally $7-17 \mu \mathrm{m}$ wide, often with very long necks, which are apically ca. $2-3 \mu \mathrm{m}$ thick; wall thin, smooth (rarely rough), inamyloid (being scarce and sometimes collapsed, the caulocystidia may appear lacking unless carefully searched for). Ecology. In rich forest or mesic heath forest, on fairly fertile ground, on decaying needles of Picea abies and Pinus sylvestris, and decaying (rarely living) stems of Vaccinium myrtillus, hiding in sheltered places, as among grass and moss, under brush, and within the humus layer; in August.

\section{Specimens examined}

Finland. Varsinais-Suomi: Lohja rural commune, Jalassaari, Heimo, asssociated with Sclerotium floccipendulum Fr., Grid 27ํ: 6682:329, 22.VIII.1984 H. \& T. Harmaja (H). Uusimaa: Helsinki, Käpylä, 29.VIII.1981 Saarenoksa 44681 $(\mathrm{H}), \quad 10$. VIII.1982 Saarenoksa 13382 (H); Viikki, 16.VIII.1982 Saarenoksa 15082 (H), 16.VIII.1982 Saarenoksa 15182 (type; H).
This tiny agaric belongs to the section Sacchariferae Kühner ex Singer and is closely related to $M$. adscendens (Lasch) Maas G. (syn. M. tenerrima (Berk.) Quél.; see Maas Geesteranus 1983). M. occulta differs from $M$. adscendens mainly in the smaller fruit bodies, the initially pale blue but soon white colours of the pileus and the stipe, the slightly thinner spores, the constantly four-spored basidia, the \pm clavate cheilocystidia without any rostrum, and the different non-ligneous substrate. In addition, $M$. occulta grows in sheltered places (see above) with a humid microclimate even in summer, a habitat probably required by this species with very small fruit bodies. All three localities known so far for the species are situated in the hemiboreal zone, at its northern border.

Acknowledgements. The loans provided by the Royal Botanic Gardens at Kew $(\mathrm{K})$, the Herbarium of the University of Uppsala (UPS), the New York State Museum (NYS), and the Virginia Polytechnic Institute and State University (VPI) are gratefully acknowledged. I am indebted to Mr. Mauri Korhonen, Mr. Reima Saarenoksa and Prof. Risto Tuomikoski for collecting critical material and for many valuable discussions. Mr. Korhonen and Dr. Tuomo Niemelä took the photographs and kindly let me publish them in the present paper. Dr. Jaakko Syrjämäki provided me with excellent conditions for studying fungi in Lammi, at the Biological Station of the University of Helsinki.

\section{References}

Arnolds, E. 1979: Notes on Hygrophorus 3. The group of Hygrophorus olivaceoalbus (Hygrophorus subsect. Olivaceoumbrini Bat.) in north-western Europe. Persoonia 10: 357-382

Gillman, L.S. \& Miller, O.K. 1977: A study of the boreal, alpine, and arctic species of Melanoleuca. - Mycologia 69: $927-951$.

Harmaja, H. 1969: The genus Clitocybe (Agaricales) in Fennoscandia. - Karstenia 10: 5-168.

- 1979: Studies in the genus Cystoderma. - Karstenia 19: $25-29$.

- 1984: Sowerbyella brevispora, a new discomycete species from Finland. - Karstenia 24: 29-30.

Hesler, L.R. \& Smith, A.H. 1963: North American species of Hygrophorus. -416 pp. Knoxville.

Maas Geesteranus, R.A. 1980: Studies in Mycenas 15. A tentative subdivision of the genus Mycena in the northern Hemisphere. - Persoonia 11: 93-120.

- 1983: Conspectus of the Mycenas of the Northern Hemisphere 1. Sections Sacchariferae, Basipedes, Bulbosae, Clavulares, Exiguae, and Longisetae. - Proc. Kon. Nederlandse Akad. Wetensch., C, 86: 401-421.

Moser, M. 1967: Beitrag zur Kenntnis verschiedener Hygrophoreen. - Zeitschr. Pilzk. 33: 1-21.

Singer, R. 1943: Das System der Agaricales 3. - Ann. Mycol. 41: 1-189.

Tuomikoski, R. 1976: Vahakkaat, Hygrophoraceae. - In: Ulvinen, T. (ed.): Suursieniopas: 53-64. Helsinki. 